\title{
AWPP in 中国に参加して 3 (初日の一般講演)
}

久 松 徳 郎*

アジア・プラスチック成形ワークショップ初日の午後は, $\mathrm{A}$ : 材料, B：加工および設備の 2 つのセッションに分か れて研究発表を行った。

それぞれのセッションについて, 興味深かった発表を幾 つか紹介する.

〈セッションA〉

○華東理工大の郭らは, PMMA の透明性を維持しなが ら耐衝撃性の改善を図ることを目的として, 表面処理した 直径 $1 \mu \mathrm{m}$ 以下の $\mathrm{SiO}_{2}$ パウダーをブレンドしてゾルーゲ ル法により厚さ $10 \mathrm{~mm}$ の板状の試料を作成した.

$\mathrm{SiO}_{2}$ の $4 \mathrm{wt} \%$ 添加により, 透明度の低下を $10 \%$ 以下に 抑えながら耐衝撃性を約 30\% 向上させることができた.

○ポリプラスチックスの小林は, LCP の高性能化のニー ズが多い中で, その成形性や機械的性質の低下を招かずに 耐熱性の改善を図る技術を開発した。

熱力学的には, 融解エンタルピーを $\mathrm{H}_{\mathrm{m}}$, 融解エントロ ピーを $\mathrm{S}_{\mathrm{m}}$ とすると, 樹脂の融点 $\mathrm{T}_{\mathrm{m}}$ は次式で表される.

$$
\mathrm{T}_{\mathrm{m}}=\Delta \mathrm{H}_{\mathrm{m}} / \Delta \mathrm{S}_{\mathrm{m}}
$$

樹脂の結晶化度を上げて $\Delta \mathrm{H}_{\mathrm{m}}$ を大きくしても, LCP 骨 格に 6-ヒドロキシ-2-ナフトエ酸からなるコポリエステル を導入することで $\Delta \mathrm{S}_{\mathrm{m}}$ がその分だけ大きくなるようにポ リマー設計することにより, 融点を変えずに耐熱性を向上 させることが可能になった。

〈セッション B $\rangle$

○四川大の王らは, 中国の伝統的な食品加工装置である パンミルを用いた固相せん断混合法によりポリマーアロイ や複合材をつくる方法について発表した. 同手法は, 従来

\footnotetext{
* Hisamatsu, Tokuro

山形大学 工学部ベンチャー・ビジネス・ラボラトリー

米沢市城南 4-3-16（テ992-8510）

2005.2.25 受理
}
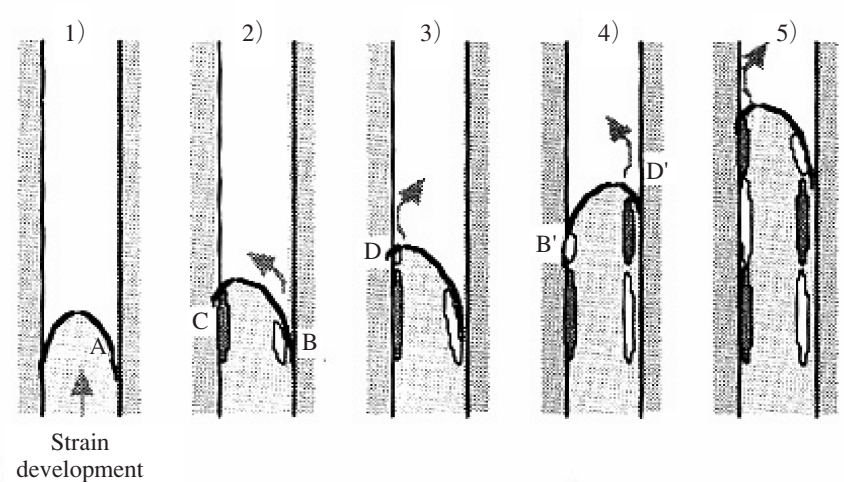

\section{フローマークの形成モデル図}

の $\mathrm{CMA}, \mathrm{S}^{3} \mathrm{E}, \mathrm{S}^{3} \mathrm{P}$ (注参照) などの混練法に比較して, 1 つのプロセスの中で粉砕, 分散, 混練および活性化が図 れる点で有利である. 複合材の開発事例として, PP に入 れたグラファイトをシェアの方向に配向させて導電性を改 善したこと, SBSにPP を練り込んでゴムの改質を行った こと, $\mathrm{PP} / \mathrm{PA}$ ブレンドの微細化により耐衝撃性の向上を 図ったことなどが紹介された。

○東京工大の斉藤らは, タルク充填 PP のフローマーク 発生原因について，レーザー顕微鏡による表面粗さの非接 触測定, DSCによる表面近傍の結晶化度測定などの分析 結果から，その発現モデルを提案した (上図参照)。すな わち, タルクを含有する PP はせん断ひずみによって局部 的な粘度低下がもたらされ, メルトフロントが不安定流動 を起こして首振り運動し, 2 枚の平行な金型表面に交互に 接触しながら充填されるために, 光沢領域と曇り領域の縞 模様が形成されると考えられる.

注) CMA : Cryogenic Mechanical Alloy $\mathrm{S}^{3} \mathrm{E}$ : Solid State Shear Extrution $\mathrm{S}^{3} \mathrm{P}$ : Solid State Shear Pulverization

\section{AWPP in 中国に参加して 4 (二日目の一般講演)}

朝からひどい霧で, 会場のあるホテルの空からはほんの 数十メートル先の景色も見えない真っ白の世界は, 翌日帰 国する予定の方々を不安にさせるものであった，時間がた つとその霧も晴れてきた，後にこの霧に悩まされた人がい たことを知ることになる.

二日目も二会場に分かれて朝八時半より講演会が行われ た. 午前中は各会場 7 件ずつの発表が予定されていた．私 が聞き逃したのだろうか，プログラムは大きく変更されて
おり，二会場をまたにかけて講演を聴こうとしていたが， どの講演がいつ行われるのかわからなくなってしまったた め, 途中からは一会場に腰を据えることにした. プログラ ムの変更や時間調整に関するアナウンスは, 中国語で行わ れていたか,または全く行われていなかったのか, 良くわか らなかったのだが，その状況にすっかり慣れてしまいこの 時点ではもう気にすることもなく，慌てずにやり過ごした。 この時間帯に少なくとも 2 件以上の中国におけるスー 
パーエンプラの開発，研究に関するご講演が吉林大学の先 生方から行われた。先生方の所属は特殊工程塑料教育部工 程研究中心とあり，まさにスーパーエンプラ（特殊工程塑 料）の開発のための機関であるとお見受けした. 大学の中 にこのような機関があるということにも，中国のプラス チック産業への入れ込みようが表れているのではないだろ うか.

そのうち一件は，まず，世界的に見たスーパーエンプラ の市場規模の解説から始まった. 1981 年から 1993 年にか け，徐々に市場規模が大きくなったが，さらに 1993 年以 降には急激な伸びがあったことがグラフで示された。一方 中国国内においては，世界的にスーパーエンプラが市場に 出回り始めた 1960 年代からすでに研究が行われており,

また, 海外メーカーの大規模なプラントも建設されたとの 説明であった。

次に吉林大学におけるスーパーエンプラに関する研究に ついての説明である.驚いたのは, 大学と企業とでスーパー エンプラを製造する合弁会社をすでに設立し，ゆくゆくは 輸出を視野にいれているとのお話であった.

もう一件, 吉林大学からの講演は, Moulding, Processing and Mould Characteristic of Super Engineering Plastics (PES and PEEK) というタイトルで, PESおよび PEEK

\footnotetext{
* Mizoguchi, Machiko

山形大学工学部 機能高分子工学科

米沢市城南 4-3-16（宁992-8510）

2005.1. 7 受理
}

の成形，物性に関するレビュー式の講演であった，講演最 後には，それら樹脂の今後の研究開発に当たっての課題が 示された．複合材料化に関する研究，樹脂単体および複合 材料の成形体の構造と物性に関する基礎研究が重要である と認識されていた。

この二日目午前中のセッションには，三菱エンジニアリ ングプラスチックス上海の三井氏のエンプラのアジアにお ける需要について講演が予定されていた。しかし, 講演の 順番が来ると, 何らかの中国語のアナウンスがあり, 昼食 時間に入ってしまった。

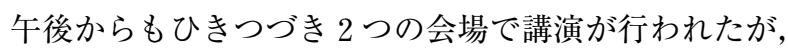
各会場 3 件ずつの発表が予定されていた. 我々日本人参加 者は会社訪問ということで, 聴講することはできなかった. 会社訪問への出発時刻になり，ホテルロビーに皆が集合し 始めたころ，三井氏が講演されているとの情報が入った。 霧が原因でフライトが遅れてしまったとのことであった。 日本人参加者の出発前ギリギリで，どうにか栗山先生，末 松会長と顔をあわせられる時間はあったものの，またすぐ に上海にお戻りになるということで，参加者全員とは親交 を深める時間もなく，大変残念なことになってしまった.

私にとっては初めての中国であったが，中国に到着して から，中国の文化に触れ，また講演会に参加し，中国側の 講演を聞いたことで，非常によく中国のプラスチック産業 の状況を知ることができ，有意義な時間を過ごすことがで きた。

\section{AWPP in 中国に参加して 5 (見学ッアー)}

塩 原 真 由 美*

すっきりと晴れた最終日はアジア・ワークショップの会 場であるホテルを後にし, 遠東工業城とプラスチック博覧 会，天童寺をバスで回り見学した.

\section{1 。遠東工業城}

11 月 8 日 8：30にホテルを後にし，まず，はじめに遠 東工業城を見学した（図 1)。この工業地区は「プラスチッ クの町」・「金型の王」として知られる浙江省余姚市内に 位置し，敷地面積は 200 ヘクタール，管理センターを中心 に工業区・生活区・商業区から構成されている．工業区に は台湾を中心に日本・オーストラリア・シンガポール・ド イツなど 40 社を超える製造業者が投資を行い, プラスチッ ク関連会社だけでなく, 電子部品・スポーツ用品・玩具な どの製造業者が集まっているとのことだ.

\section{2 . 信息中心（情報センター）・塑料博覧会（プラス チック博覧会)}

余姚市が「プラスチックの町」・「金型の王」として知 られていることを象徴するような場所が，プラスチック博 覧会会場周辺の道路沿いにあった。そこには成形機や材料

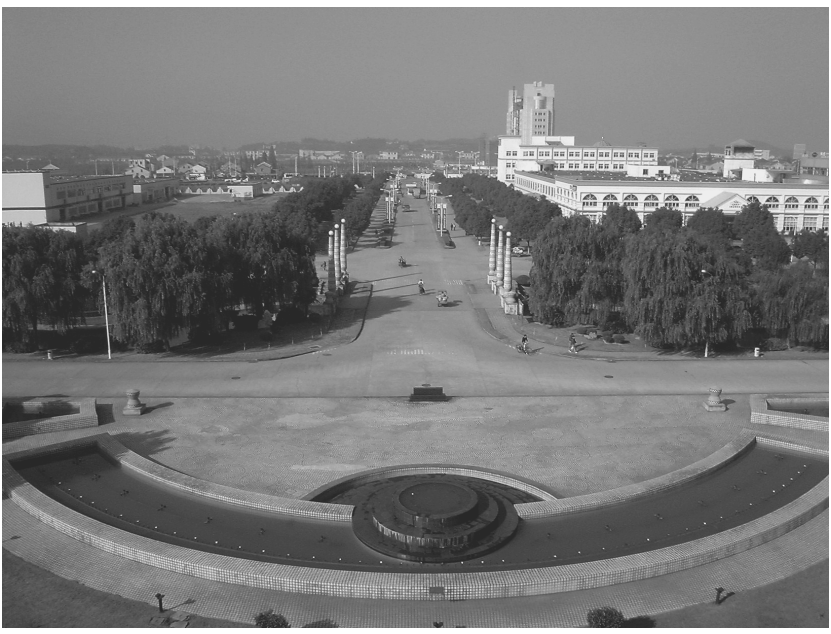

図 1 遠東工業城

を取扱う店が $2 \mathrm{~km} に わ た り$ 軒を連ねており，街頭に射出 成形機を展示している店（図 2）や，材料を山のように積 んである店が車空からみられた。

射出成形機が並んでいる通りをバスでしばらく行ったと 